\title{
Pengaruh Budaya Terhadap Keputusan Membeli Produk Mie Instant Indomie
}

\author{
Denny Asmas, Ahmad Tarmizi \\ Fakultas Ekonomi Universitas Batanghari Jambi, Indonesia \\ Correspondence email: dennyandhora4@gmail.com
}

\begin{abstract}
Indomie Instant Noodle is one of the products of instant noodles favored by consumers because it produces a variety of variations that are in the form of fried noodles (ordinary fried noodles, special fried foods, noodles club taste roasted chicken, jumbo fried noodles) and in the form of Mie Kuah (flavored chicken broth, chicken curry flavor, onion chicken flavor, special chicken flavor, Soto Ayam flavor). Indomie instant noodle products that are made in a variety of variations are tailored to the tastes of consumers who are also varied, which are always changing as the environment changes, also according to the consumer behavior itself. Therefore, every production of instant noodle Indomie always produce various products that are varied and adjusted to the condition of the region. This research aims to analyse the influence of cultural variables on the decision to purchase Indomie instant noodle products. The results of this study showed that there was a significant influence of the cultural variables on Indomie instant noodle product purchasing decision.
\end{abstract}

Keyword: culture, consumers, buying decisions

\section{PENDAHULUAN}

Banyaknya produk mie instant yang bermunculan dengan menunjukan keunggulan-keunggulannya, merupakan tersedianya banyak alternatif pembelian bagi konsumen. Bila dilihat dari kacamata produsen, banyaknya alternatif pembelian tersebut mengakibatkan persaingan yang tajam bagi produsen. Oleh karena itu perusahaan harus lebih banyak berorientasi pada konsumen karena penyesuaian terhadap kebutuhan dan keinginan konsumen merupakan salah satu syarat bagi perusahaan dalam persaingan. Tabel 1 data perbandingan persentase penjualan produk mie instant indomie, mie sedap, dan sarimie.

Tabel 1

Persentase Perbandingan Penjualan Produk Mie Instant Tahun 2014 - 2018

\begin{tabular}{cccc}
\hline Tahun & Indomie (\%) & Mie sedap (\%) & Sarimie (\%) \\
\hline 2014 & 48,3 & 40,10 & 11,5 \\
2015 & 52,6 & 38,2 & 9,2 \\
2016 & 58,3 & 39,1 & 2,6 \\
2017 & 60,1 & 36,8 & 3,1 \\
2018 & 66,3 & 32,5 & 2,2 \\
\hline
\end{tabular}

Sumber: Indofood Group, wings group tahun 2018

Mie instant Indomie merupakan salah satu produk mie instant yang digemari konsumen karena memproduksi berbagai variasi yaitu dalam bentuk mie goreng (mie goreng biasa, mie kriting goreng special, mie kriting rasa ayam panggang, mie goreng jumbo) dan dalam bentuk mie kuah ( rasa kaldu ayam, rasa kare ayam, rasa ayam bawang, rasa ayam special, rasa soto ayam). Produk mie instant Indomie yang dibuat dalam berbagai variasi ini disesuaikan dengan selera konsumen yang juga bervariasi, yang selalu mengalami perubahan seiring dengan perubahan lingkungan, juga sesuai dengan perilaku konsumen itu sendiri. Sehingga setiap produksi mie instan indomie senantiasa menghasilkan berbagai produk yang variatif dan disesuaikan dengan kondisi daerah. Berikut data penjualan produk mie Instant indomie skala 5 tahun terakhir 
Tabel 2

Data Penjualan Mie Instant Indomie PT.Indofood Sukses Makmur Jambi Tahun 2014 - 2018

\begin{tabular}{ccc}
\hline Tahun & Penjualan/dus & Perkembangan $(\%)$ \\
\hline 2014 & 13.250 & 3,75 \\
2015 & 13.747 & 5,70 \\
2016 & 14.531 & 1,80 \\
2017 & 14,793 & 6,20 \\
2018 & 15.710 & 4,36 \\
Rata-rata & & \\
\hline
\end{tabular}

Sumber: PT.Indofood Sukses Makmur Jambi, Tahun 2018

Tabel 2 memberikan gambaran bahwa selama periode 2014-2018 penjualan Mie Instant Indomie PT.Indofood Sukses Makmur Jambi menunjukkan kecenderungan yang meningkat dari tahun ke tahun, dengan rata-rata peningkatan penjualan sebesar 4,36 persen per tahun. Peningkatan ini menggambarkan bahwa produk Mie Instant Indomie PT.Indofood Sukses Makmur Jambi digemari masyarakat. Perilaku konsumen sebagai tindakan yang langsung terlibat dalam mendapatkan, mengkonsumsi dan menggunakan produk dan jasa termasuk proses keputusan yang mendahului dan mengikuti tindakan pembelian, sedangkan dalam memutuskan untuk membeli, konsumen membutuhkan suatu pertimbangan mengenai ciri-ciri dari produk yang akan dibeli. Pemahaman tentang konsumen dapat dilakukan dengan penelitian sehingga dapat mengukur dan menilai keinginan sikap serta perilakunya. Meningkatnya jumlah penduduk, khususnya di Kelurahan Telanaipura Kecamatan Telanaipura akan memberikan implikasi yang luas juga terhadap keputusan pembelian produk mie instant. Adapaun gambaran jumlah penduduk di Kelurahan Telanaipura tergambar pada tabel berikut:

Tabel 3

Data Jumlah Penduduk Kelurahan Telanaipura Tahun 2014 - 2018

\begin{tabular}{cccc}
\hline Tahun & Jumlah penduduk laki-laki/Jiwa & Jumlah penduduk perempuan/jiwa & Total penduduk \\
\hline 2014 & 8.315 & 8.060 & 16.375 \\
2015 & 8.482 & 8.321 & 16.803 \\
2016 & 8.610 & 8.321 & 16.931 \\
2017 & 8.736 & 8.505 & 17.241 \\
2018 & 8.950 & 8.612 & 17.562 \\
& Total & & 84.912 \\
\hline
\end{tabular}

Sumber : Kelurahan Telanaipura tahun 2018

Berdasarkan Tabel 3 tergambar bahwa selama periode 2014-2018 jumlah penduduk di Kelurahan Telanaipura Kecamatan Telanaipura menunjukkan kecenderungan yang meningkat. Peningkatan ini sudah barang tentu akan memberikan dampak terhadap tingkat konsumsi masyarakat, khususnya dalam mengkonsumsi Mie Instant Indomie PT.Indofood Sukses Makmur Jambi. Tujuan dari penelitian ini adalah untuk menganalisis pengaruh variabel budaya terhadap keputusan membeli produk mie instant Indomie

\section{Landasan Teori}

\section{Faktor-faktor yang Mempengaruhi Perilaku Konsumen Faktor intern}

1. Faktor budaya

Kebudayaan adalah simbol dan fakta yang komplek yang diciptakan oleh manusia, diturunkan dari generasi ke generasi sebagai penentu dan pengatur tingkah laku manusia dalam masyarakat yang ada. Faktor budaya mempunyai pengaruh yang paling luas dan mendalam terhadap perilaku konsumen, karena kebudayaan merupakan faktor penentu keinginan dan perilaku seseorang yang paling mendasar.

a. Kultur, Kultur adalah determinan yang paling fundamental dari keinginan dan perilaku seseorang, kultur mengacu pada nilai, gagasan, simbol-simbol yang memiliki makna untuk berkomunikasi, melakukan pengarsiran dan evaluasi sebagai anggota masyarakat.

b. Sub-kultur, Setiap kultur terdiri dari sub-sub kultur yang lebih kecil yang memberikan identifikasi dan sosialisasi anggotanya yang lebih spesifik. Sub-kultur mencakup : kebangsaan, agama, kelompok ras dan daerah geografis. 
c. Kelas sosial, Menurut Kotler diterjemahkan oleh Teguh dan Ronny A Rusli (2007:155): "Kelas sosial adalah bagian-bagian yang relative homogeny dan tetap dalam suatu masyarakat, yang tersusun secara hirarkis dan anggota-anggotanya mempunyai tata nilai minat dan perilaku-perilaku yang serupa". Kelas sosial kadang-kadang berupa suatu sistem kusta dimana anggota dari kasta yang berbeda dibesarkan untuk peranan-peranan tertentu dan tidak dapat mengubah keanggotaan kasta mereka.Kelas sosial diukur sebagai kombinasi dari pekerjaan, penghasilan, pendidikan, kekayaan dan variabel lainnya.

2. Faktor sosial

Perilaku konsumen juga dipengaruhi oleh faktor-faktor sosial, antara lain adalah :

a. Kelompok acuan, kelompok acuan terdiri dari semua kelompok yang mempunyai pengaruh langsung atau tidak langsung yang terjadi akibat interaksi secara formal maupun informal terhadap pendirian atau perilaku seorang.

b. Keluarga, Orientasi keluarga menunjukan keterlibatan suami istri serta anggota keluarga lainnya dalam proses pengambilan keputusan pembelian.

c. Peran dan status, Seorang berpartisipasi diberbagai kelompok dalam hidupnya : keluarga, klub atau organisasi. Posisi organisasi tersebut dalam setiap kelompoknya dapat didefinisikan dalam istilah peran dan status.

3. Faktor pribadi

Menurut Kotler dan Armstrong yang diterjemahkan oleh Bakowatun (2002:161) menyatakan bahwa Kepribadian sebagai karakteristik psikologis yang berbeda dari seseorang yang menyebabkan tanggapan yang relatif konsisten dan bertahan lama terhadap lingkungannya. Perilaku seseorang dalam membeli sesuatu juga dipengaruhi oleh faktor-faktor kepribadian dari konsumen yang bersangkutan. Adapun faktor-faktor tersebut adalah :

a. Umur dan tahap siklus hidup, Tingkatan kehidupan adalah tahap-tahap yang akan dilalui keluarga ketika mereka tumbuh dewasa di sepanjang masa.

b. Pekerjaan, Pekerjaan yang ditekuni seseorang akan mempengaruhi pola konsumsinya, sehingga perusahaan dapat melakukan spesialisasi dalam meawarkan produknya.

c. Kondisi ekonomi, Konsumen didalam melakukan pembelian tidak terlepas dari kondisi ekonominya, dimana dengan kondisi ekonomi yang memadai dapat menunjukan kemampuan di dalam mengkonsumsi suatu jenis barang dan jasa.

d. Gaya hidup, Gaya hidup mencerminkan sesuatu yang lebih berkelas sosial dan gaya hidup juga melukiskan keseluruhan orang yang berinteraksi dengan lingkungannya.

e. Kepribadian dan konsep diri, Kepribadian merupakan karakteristik psikologis yang unik yang menyebabkan tanggapan diri seseorang yang relatif konsisten dan tetap tahan lama terhadap lingkungannya sendiri. Kepribadian biasanya dijelaskan dengan ciri-ciri bawaan seperti : kepercayaan diri, perbedaan rasa hormat, kondisi sosial, kekuasaan, kemampuan, beradaptasi dan kestabilan emosi.

4. Faktor psikologis

Pilihan pembelian seseorang dipengaruhi oleh empat faktor psikologis utama yaitu: motivasi, persepsi, pengetahuan, kepercayaan dan sikap.

a. Motivasi, Suatu kebutuhan akan menjadi motif bila telah mencapai tingkat intensitas yang cukup. Motif atau dorongan adalah suatu kebutuhan yang cukup mendorong seseorang untuk bertindak.

b. Persepsi, Menurut Kotler yang diterjemahkan oleh Wasana (2001:248) persepsi dirumuskan sebagai "Proses seorang indvidu untuk memilih, mengorganisasi dan menafsirkan masukan-masukan informasi untuk menciptakan sebuah gambar yang bermakna tentang dunia".Persepsi menjembatani seseorang dalam membuktikan kenyataan melalui rangsangan yang diterima manusia dengan panca indera. Tanggapan persepsi pada setiap orang berbeda karena adanya proses penerimaan rangsangan secara selektif

c. Pengetahuan. Menurut Kotler yang diterjemahkan oleh Tjiptono (2009:242) mengemukakan bahwa: "Pengetahuan menggambarkan perubahan dalam perilaku individu tertentu yang berasal dari pengalaman".Teori pengetahuan mengajarkan kepada para pemasar agar dapat menciptakan 
permintaan akan suatu produk dan menghubungkannya dengan dorongan yang kuat, menggunakan petunjuk yang memotivasi dan memberikan penguatan yang positif.

d. Kepercayaan dan sikap. Menurut Kotler dan Armstrong yang diterjemahkan Bakowatun (2005:246) Kepercayaan adalah suatu pemikiran deskriptif yang dimiliki seseorang tentang sesuatu, sedangkan sikap adalah evaluasi, persatuan dan kecenderungan seseorang yang relatif konsisten terhadap suatu obyek atau gagasan. Melalui berbuat dan belajar, akan terbentuk suatu kepercayaan. Kepercayaan ini selanjutnya akan mempengaruhi perilaku seseorang. Kepercayaan ini juga membentuk citra produk atau merk tersebut.Jika terdapat kepercayaan yang salah dan mengekang pembelian, pemasaran harus berkampanye untuk memperbaiki kepercayaan yang salah itu dan jangan sampai kepercayaan itu membuat kesan yang merugikan terhadap merk dan produk itu sendiri. Sikap seseorang dalam menghadapi suatu produk dapat dibagi menjadi dua yaitu sikap positif dan sikap negative.Sikap positif berarti senang pada produk tersebut, sedangkan sikap negative berarti tidak menyenangi produk yang bersangkutan. Menurut Engel yang diterjemahkan oleh Budiyanto (2004:106), fungsi sikap terbagi menjadi 4 yaitu :

1) Fungsi guna. Sikap menuntut konsumen untuk mencapai kebutuhan yang diinginkan. Pada fungsi guna ini, sikap akan membuat konsumen yang menghindari merk yang tidak dapat memenuhi kebutuhan mereka. Jadi karena guna merk itulah konsumen mempertahankan merk tertentu.

2) Fungsi nilai

Sikap mengekspresikan konsep diri dan sistem niai.Jadi fungsi nilai merupakan perwujudan dari citra dari individu dalam memilih suatu produk.

3) Fungsi pertahanan ego

Sikap menimbulkan rasa untuk melindungi ego dari kegelisahan/ancaman.

4) Fungsi perorganisasian pengetahuan

Fungsi pengetahuan mengelompokkan informasi. Hal ini akan membantu konsumen melakukan pemrosesan informasi.

Adapun Komponen sikap meliputi dari beberapa macam diantaranya :

a) Komponen kognitif, adalah kepercayaan konsumen yang diperoleh melalui proses informasi dan pengalaman langsung terhadap obyek dan dari informasi dan eksternal dari individu terhadap suatu obyek.

b) Komponen efektif, adalah reaksi konsumen terhadap atribut yang terdapat dalam kepercayaan.Reaksi ini dapat berupa pernyataan sangat baik, sangat buruk, dan sebagainya.

c) Komponen perilaku, meripakan komponen akhir yang mempertimbangan kemungkinan, tendensi atau kecenderungan dimana individu akan melakukan suatu tindakan tertentu.

\section{Faktor ekstern}

1. Harga. menurut Kotler dan Armstrong yang diterjemahkan oleh Nurmawan (2007:339) "Harga adalah jumlah nilai yang konsumen pertukarkan untuk mendapatkan manfaat dari memiliki atau menggunakan produk atau jasa. Salah satu faktor yang mempengaruhi minat beli konsumen adalah harga. Harga merupakan faktor penentuan dari permintaan pasar untuk suatu produk dan jasa karena dapat mempengaruhi pangsa pasarnya.Bagi produsennya, harga harus dapat memberikan hasil dengan menciptakan pendapatan dari keuntungan bersih. Harga memiliki dua peranan utama dalam prosess pengambilan keputusan para pembeli yaitu peranan alokasi dan peranan informasi (Tjiptono, 2007:152).

a. Peranan alokasi dari harga, yaitu fungsi harga dalam membantu para pembeli untuk memutuskan cara memperoleh manfaat tertinggi yang diharapkan berdasarkan daya belinya. Dengan demikian, adanya harga dapat membantu para pembeli untuk memutuskan cara mengalokasikan daya belinya pada berbagai jenis barang dan jasa. Pembeli membandingkan harga dari berbagai alternatif yang tersedia, kemudian memutuskan alokasi dana yang dikehendaki.

b. Peranan informasi dari harga, yaitu fungsi harga dalam memdidik konsumen mengenai faktor-faktor produk seperti kualitas. Hal ini terutama bermanfaat dalam situasi dimana pembeli mengalami kesulitan untuk menilai faktor produk atau manfaatnya secara obyektif. Persepsi yang sering berlaku adalah bahwa harga yang mahal mencerminkan kualitas yang tinggi. 
2. Produk. Menurut Kotler dan Armstrong yang diterjemahkan oleh Bakowatun (2002:347) "Produk adalah sesuatu yang dapat ditawarkan ke pasar untuk mendapatkan perhatian, untuk dibeli, digunakan atau dikonsumsi yang dapat memenuhi suatu keinginan atau kebutuhan. Menurut Kotler dan Armstrong terjemahan Bakowatun (2002:350) bahwa produk dapat dibagi menjadi tiga kelompok menurut keberwujudannya, yaitu :

a. Barang tidak tahan lama. Barang tidak tahan lama adalah barang konsumsi yang biasanya dikonsumsi dalam satu atau beberapa kali penggunaan. Contoh : makanan dan minuman.

b. Barang tahan lama. Barang tahan lama adalah barang konsumsi yang digunakan selama kurun waktu yang panjang dan biasanya tetap bertahan hingga beberapa kali pemakaian. Contoh : pakaian, perabot rumah tangga.

c. Barang jasa atau pelayanan. Barang jasa atau pelayanan adalah kegiatan, manfaat atau kepuasan yang ditawarkan untuk dijual. Contoh : pemeriksaan dokter, pemangkasan rambut.

\section{Hubungan faktor budaya terhadap keputusan pembeliaan}

Faktor kebudayaan berpengaruh luas dan mendalam terhadap perilaku pembelian konsumen dalam faktor kebudayaan ini terdapat beberapa komponen antara lain: budaya yang merupakan faktor menentu paling mendasar dari segi keinginan dan perilaku seseorang karena kebudayaan menyangkut segala aspek. Menurut Kotler (2005:224) keudayaan adalah deteriman paling fundamental keinginan dan perilaku konsumen. sub, budaya terdiri dari kebangasaan, agama, kelompok, ras, dan daerah geografis. Banyak suku budaya yang membentuk segmen pasar penting, dan pemasar sering merancang produk dan program pemasaran yang disesuaikan dengan kebutuhan mereka agar produk yang dihasilkan dapat sesuai dengan selera pasar.

\section{Hipotesis}

Diduga faktor budaya secara parsial berpengaruh positif terhadap keputusan pembelian

\section{METODE}

Populasi data penelitian ini seluruh konsumen di daerah Kelurahan Telanaipura Kecamatan Telanaipura dengan jumlah populasi sebanyak 17.562 jiwa. Sampel merupakan bagian dari populasi yang akan diteliti. Baik tidaknya penentuan sampel akan berpengaruh terhadap validasi penelitian. Pengambilan sampel dalam penelitian ini menggunkan teknik purpositive random sampling. Purposive random sampling merupakan teknik pengambilan sampel dengan memperhatikan pertimbangan-pertimbangan yang dibuat oleh penelitian Hadi, (2004:65). Purposive sampling ini dilakukan dengan cara mengambilan subyek bukan didasarkan atas strata, random/daerah tetapi berdasarkan atas dasar adanya tujuan tertentu. Alat yag dimaksud adalah alat yang diadakan dan disesuaikan dengan metode yang digunakan dalam pengumpulan data. Menurut Slovi dan Husein Umar (2011:78) dengan rumus sebagai berikut:

$\mathrm{n}=\frac{\mathrm{N}}{1+N e^{2}}$

Dimana: $\mathrm{n}=$ Ukuran sample; $\mathrm{N}=$ Ukuran populasi; $\mathrm{e}=$ Persen kelongaran ketidakteletian karena kesalahan pengambila sampel yang masih dapat ditolerir atau diinginkan, misal 10\%

$\mathrm{n}=\frac{17.562}{1+17.562(0,1)^{2}} \mathrm{n}=99,90$ dibulatkan 100 sampel

Metode analisis data yang digunakan adalah deskritif kuantitatif adalah metode yang dapat diartikan sebagai metode penelitian yang berlandaskar pada filsafat positivisme, digunakan untuk menelti pada populasi atas sampel tertentu, teknik pengambilan sampel pada umumnya bersifat random, pengumpulan data menggunkan instrument peneltian, analsisi data bersifat kuantitatif atau statistic dengan tujuan untuk menguji hipotesis yang telah ditetapkan. Untuk mengetahui pengaruh budaya dan keputusan pembelian digunakan rumus regresi. menurut Priyanto : (2013-131)

$\mathrm{Y}=\mathrm{a}+\mathrm{bX}+\mathrm{e}$

dimana : $\mathrm{Y}=$ Keputusan Pembelian; $\mathrm{b}=$ Koefesien Regresi; $\mathrm{a}=$ Konstanta; $\mathrm{X}=$ Budaya; $\mathrm{e}=$ Standar Error

Koefesien kolerasi ialah pengukuran statistic kovarian atau asosiasi antara 2 variabel. Besarnya koefesien kolerasi berkisaran +1 sampai dengan -1 koefesien kolerasi menunjukan kekuatan hubungan linier dan arah hubungan 2 variabel secara acak. Jika koefesien kolerasi positif maka kedua koefesien mempunyai 
hubungan searah. Artinya, jka nilai variabel X tinggi, maka nilai variabel Y akan tinggi pula. Sebaliknya, jika koefesien kolerasi negative maka kedua variabel mempunyai hubungan terbalik. Artinya, jika nilai variabel $\mathrm{X}$ tinggi maka nilai variabel $\mathrm{Y}$ akan menjadi rendah (dan sebaliknya). Untuk memudahkan melakukan interprestasi mengenai kekuatan hubungan antara dua variable kriterianya sebagai berikut: 0 : Tidak ada kolerasi antara dua variabel; > 0-0,25 : Kolerasi sangat lemah; > 0,25-0,5 : Kolerasi cukup; > 0,50,75 : Kolerasi kuat; > 0,75-0,99 : Kolerasi sangat kuat; dan 1: Sempurna.

Analisa determinasi digunakan untuk mengetahui persentase sumbangan variabel bebas (independen) secara bersama-sama terhadap variabel terikat (depenen). Koefesien determinasi menunjukan seberapa besar persentaase variasi variabel bebas yang digunakan dalam model mampu menjelaskan variasi variabel terikat Priyanto (2013:143). Koefesien determinasi disimbolkan dengan $r^{2}$ adalah sebuah besaran yang mengukur ketepatan garis regresi. Maksimum $\mathrm{r}^{2}$ adalah $100 \%$ dan minimal 0 . Jika $\left(\mathrm{R}^{2}\right)$ yang diperoleh mendekati 1(satu) maka dapat dikatakan semakin kuat model tersebut menerangkan hubungan variabel bebas terhadap variabel terikat. Sebaliknya jika $\left(\mathrm{R}^{2}\right)$ makin mendekati 0 (nol), maka semakin lemah pengaruh variabelvariabel bebas terhadap variabel terikat. Model umum persamaan regresi adalah sebagai berikut:

$\mathrm{R}^{2}=\mathrm{r} \times \mathrm{r}$

Dimana $: \mathrm{R}^{2}=$ koefesien determinasi; $\mathrm{r}=$ koefesien kolerasi

\section{Uji statistk $t$}

Rumusan Hipotesis:

$\mathrm{H} 0 ; \mathrm{b}=0$, artinya variabel independen $\mathrm{X}$ secara individual tidak berpengaruh terhadap variabel dependen $\mathrm{Y}$ $\mathrm{H} 1 ; \mathrm{b} \neq 0$, artinya variable; $\mathrm{X}$ secara individual berpengaruh terhadap variabel dependen $\mathrm{Y}$

Tingkat signifikan 5\% $(\alpha=0,05)$

Keriteria keputusan: t hitung > t tabel berarti $\mathrm{HO}$ ditolak dan menerima $\mathrm{H} 1$; $\mathrm{t}$ hitung < tabel berarti $\mathrm{HO}$ diterima dan menolak $\mathrm{H} 1$

uji t juga bisa dihilat pada tingkat signifikasinya : Jika tingkat signifikansi $<0,05$, maka HO ditolak dan $\mathrm{H} 1$ diterima; Jika tingkat sgignifikasi >0,05, maka $\mathrm{HO}$ diterima dan $\mathrm{H} 1$ ditolak

\section{HASIL}

\section{Pengaruh Budaya Terhadap Keputusan Pembelian Produk Mie Instan Indomie}

Sebelumnya telah diuraikan bagaimana hubungan antara variabel independen (Variabel budaya ) dengan Keputusan Pembelian Produk Mie Instan Indomie. Selanjutnya akan diuji pengaruh dari variabel independen (variabel budaya) terhadap Keputusan Pembelian produk Mie Instan Indomie baik secara simultan maupun secara parsial menggunakan analisis regressi. Dari hasil pengolahan data menggunakan software SPSS 22.00 diperoleh hasil sebagai berikut.

Tabel 4

Nilai-nilai Koefisien Regresi

\begin{tabular}{|c|c|c|c|c|c|c|}
\hline & \multicolumn{2}{|c|}{ Unstandardized Coefficients } & \multicolumn{4}{|c|}{ Standardized Coefficients } \\
\hline & B & Std. Error & Beta & & $\mathrm{t}$ & Sig. \\
\hline (Constant) & 21.380 & 3.387 & & & 6.313 & .000 \\
\hline Budaya & .226 & .098 & & .028 & 2.306 & .025 \\
\hline
\end{tabular}

Sumber: data olahan

Hasil pengolahan data seperti yang terlihat pada Tabel 4.5 maka dapat dibentuk model persamaan regressi variabel budaya terhadap variabel Keputusan Pembelian produk Mie Instan Indomie sebagai berikut.

$\mathrm{Y}=21,380+0,226 \mathrm{X}+\mathrm{e}$

Keterangan: X : Variabel budaya; Y : Keputusan Pembelian produk mie instan indomie

Nilai koefisien variabel X (budaya) yang bertanda positif pada model di atas menunjukkan bahwa perubahan yang terjadi pada variabel budaya searah dengan perubahan yang terjadi pada Keputusan Pembelian produk mie instan indomie. 


\section{Pengujian Koefisien Regressi Secara Parsial}

Pengujian koefisien regresi secara parsial (individual) merupakan kelanjutan dari pegujian koefisien regresi secara bersama-sama, dimana apabila pada pengujian koefisien regresi secara bersama-sama H0 ditolak, artinya ada diantara ke dua variabel independen yang berpengaruh signifikan terhadap variabel dependen, maka untuk menguji lebih lanjut variabel independen mana yang pengaruhnya signifikan dilakukan uji parsial (individual).

\section{Pengaruh Budaya Terhadap Keputusan Pembelian produk mie instan indomie}

Tabel 4 dapat dilihat bahwa nilai t-hitung variabel budaya sebesar 2,306, karena nilai t-hitung $(2,306)$ lebih besar dari $\mathrm{t}_{\text {-Tabel }}(1,684)$ maka pada tingkat kekeliruan 5\% H0 ditolak H1 diterima, sehingga dengan tingkat kepercayaan 95\% dapat disimpulkan bahwa terdapat pengaruh yang signifikan dari variabel Budaya terhadap Keputusan Pembelian produk Mie Instan Indomie. Berdasarkan hasil pengujian hipotesis maka dapat ditarik kesimpulan bahwa Budaya yang makin terkenal akan menyebabkan Keputusan Pembelian produk Mie Instan Indomie makin meningkat.

\section{Koefisien Determinasi}

Tabel 5

Model Summary ${ }^{b}$

\begin{tabular}{|c|c|c|c|c|c|}
\hline Model & $\mathrm{R}$ & R Square & Adjusted R Square & $\begin{array}{l}\text { Std. Error of the } \\
\text { Estimate }\end{array}$ & Durbin-Watson \\
\hline 1 & $.802^{a}$ & .643 & .713 & 2.94826 & 2.051 \\
\hline
\end{tabular}

Sumber: data olahan

Tabel 5 di atas dapat dilihat bahwa besarnya koefisien determinasi atau (R Square) dari hasil regressi variabel independen (Variabel budaya) terhadap Keputusan Pembelian produk Mie Instan Indomie sebesar 0,643. Jadi berdasarkan hasil penelitian diketahui besarnya pengaruh variabel budaya terhadap Keputusan Pembelian produk Mie Instan Indomie adalah 64,3 persen, sementara sisanya sebesar 35,7\% dipengaruhi oleh faktor-faktor lain.

\section{SIMPULAN}

1. Berdasarkan hasil perhitungan reliabilitas dengan uji statitik Cronbach Alpha $(\alpha)$, sebuah variabel dikatakan reliabel jika memberikan nilai cronbach alpha $>0,60$. Dengan demikian dipastikan semua pertanyaan reliabel atau shahih dalam mengukur variabel yang diteliti

2. Nilai koefisien korelasi antara variabel Budaya dengan Keputusan Pembelian adalah sebesar 0,203 dengan arah positif. Hubungan antara variabel Budaya dengan Keputusan Pembelian produk Mie Instan Indomie termasuk dalam kategori hubungan yang sangat kuat atau erat.

3. Nilai t-hitung variabel budaya sebesar 2,306 , karena nilai $t_{\text {-hitung }}(2,306)$ lebih besar dari $t_{\text {-tabel }}(1,684)$ maka pada tingkat kekeliruan 5\% H0 ditolak H1 diterima, sehingga dengan tingkat kepercayaan 95\% dapat disimpulkan bahwa terdapat pengaruh yang signifikan dari variabel budaya terhadap Keputusan Pembelian produk Mie Instan Indomie.

\section{DAFTAR PUSTAKA}

Ali, Hapzi. 2013. Metodelogi penelitian. Deepublish, Yogyakarta

Arikunto, Suharsimi, 2003. Manajemen Penelitian. Edisi Revisi II . PT. Rineka cipta. Jakarta.

Bakowatun, Wilhemus W, 2002. Dasar-Dasar Pemasaran.Edisi Kelima. Jilid I. Intermedia. Jakarta. 2005. Dasar-Dasar pemasaran. Intermedia. Jakarta.

Budiyanto, F.X. James F, Engel. 2004. Perilaku Konsumen. Binarupa Aksara. Jakarta

George R, Terry. 2000. Prinsip-Prisip Manajemen. (Edisi Bahasa Indonesia). PT Bumi Aksara. Bandung Hadi, Sutrisno. 2004. Metodelogi Research. Jilid Tiga. Andi. Jakarta

Hasibuan, Malayu. 2002. Manajemen Dasar Pengertian Dan Masalah. Edisi Revisi. Bumi Aksara. Jakarta

Kotler, Philp. 2000. Manajemen Pemasaran. Jilid II. PT. prenhallindo. Jakarta

Manullang M. 2008. Dasar-Dasar Manajemen. Gadjah Mada University. Press. Yogyakarta 
Mangkunegara, A.A. 2003. Perilaku Konsumen. PT, Ersco. Bandung

Nurmawan, Iman. 2007. Prinsip-Prinsip Pemasaran. Edisi Ketiga. Jilid I. Erlangga. Jakarta

Priyanto, Dwi. 2013. Olah Data Statistik Dengan Program SPSS. PT. Buku Seru. Yogyakarta

Swastha, Basu. 2007. Manajemen Pemasaran Modern. Edisi Kedua. Liberty. Yogyakarta

Tjiptotno, Fandy. 2002. Strategi Pemasaran. Edisi Kedua. Cetakan Keenam. Andy. Yogyakarta

Teguh, Hendra Dan Ronny A. Rusli. 2007. Manjemen Pemasaran. Edisi Bahasa Indonesia. Jilid I. Prenhalido. Jakarta

Tjiptono, Fandy. 2005. Strategi Pemasaran. Cetakan Pertama. Edisi Pertama. Offset. Yogyakarta . 2007. Strategi Pemasaran. Edisi Kedua. Offset. Yogyakarta

Tjiptono, Fandy. Kotler. Manajemen Pemasaran Perspektif Asia. Andi. Yogyakarta

Umar, Husein. 2011.Metode Penelitian. PT. Raja Grafindo. Jakarta

Wasana, Jaka. Kotler. 2001. Manajemen Pemsaran. Edisi Keenam. Jilid I. Erlangga. Jakarta 